\title{
DESCRIPTION OF PROSOCIAL BEHAVIOR IN YOUNG CHILDREN WITH INTELLECTUAL DISABILITY IN EAST NUSA TENGGARA ${ }^{\mathrm{a}}$
}

\author{
Beatriks Novianti Kiling-Bunga ${ }^{1, a}$, \\ Kresensia Wea Aga Ngawas ${ }^{2, a}$, \\ Indra Yohanes Kiling ${ }^{3, b}$
}

\author{
${ }^{a}$ Teaching and Education Faculty, Early Childhood Education Teacher Program \\ Universitas Nusa Cendana \\ Jl. Adisucipto, Penfui-Kupang, \\ Nusa Tenggara Timur 85001, Indonesia \\ ${ }^{b}$ Institute of Resource Governance and Social Change \\ Jl. R. W. Monginsidi II, Kec. Kelapa Lima \\ Nusa Tenggara Timur 85001, Indonesia

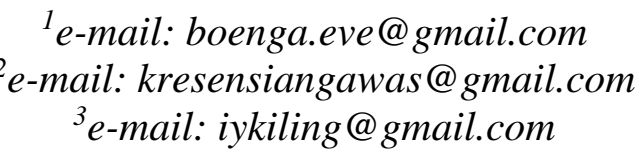

Part of this paper was presented at the International Conference of Early Childhood Education 2014, Universitas Pendidikan Indonesia, 18-19 November 2014 in Bandung

\begin{abstract}
World Health Organization and United Nations Children's Fund have stated in year 2012 that one of their global agenda is to fulfill the needs of inclusive Early Childhood Care and Development (ECCD) to increase the participation and development of young children with disabilities. One of important things for the agenda are understanding various special needs of young children with various kind of mental disability, such as mental retardation or nowadays known as intellectual disability. This research aims to narratively describe the prosocial behaviors of a young child with intellectual disability in special school of Pembina Kupang, East Nusa Tenggara. This research used qualitative approach with child observation and interview to the parents as the main technique to gather data. This research shows that prosocial behaviors in young children with intellectual disability are divided into four aspects, those are: a) the ability to join groups, b) supportive acts, c) empathy and caring, and d) self-adjustment. These behaviors were shown in the child's daily activities, her habits, affected by the culture and daily activities of her parents and siblings, and also by the interaction with her friends and family. This research could give important information about the importance of managing the social interaction in inclusive ECCD by putting emphasis in four aspects described above, and also the
\end{abstract}


role of parents and ECCD tutors in facilitating activities that could help stimulate specific needs of social skills in young children with intellectual disability.

Keywords: prosocial; young children; intellectual disability

\begin{abstract}
Abstrak - World Health Organization dan United Nations Children's Fund telah menyatakan pada tahun 2012 bahwa agenda global mereka adalah untuk memenuhi kebutuhan Pendidikan Anak Usia Dini (PAUD) inklusif, salah satunya untuk meningkatkan partisipasi dan perkembangan anak-anak dengan disabilitas. Salah satu hal penting untuk agenda ini adalah pemahaman terhadap berbagai kebutuhan khusus anak-anak dengan berbagai jenis disabilitas mental, seperti retardasi mental atau saat ini dikenal sebagai disabilitas intelektual. Penelitian ini bertujuan untuk menggambarkan secara naratif mengenai perilaku prososial anak muda dengan disabilitas intelektual di sekolah khusus Pembina Kupang, Nusa Tenggara Timur. Penelitian ini menggunakan pendekatan kualitatif dengan melakukan observasi pada anak dan wawancara dengan orangtua, sebagai teknik utama untuk mengumpulkan data. Penelitian ini mendapatkan bahwa perilaku prososial pada anak-anak dengan disabilitas intelektual dibagi menjadi empat aspek, yaitu: a) kemampuan untuk bergabung dengan grup, b) tindakan yang mendukung perilaku prososial, c) empati dan peduli, serta d) penyesuaian diri. Perilaku ini ditunjukkan dalam kegiatan seharihari anak, kebiasaannya, dipengaruhi oleh budaya dan kegiatan sehari-hari dari orangtua dan saudaranya, juga oleh interaksi dengan teman-teman dan keluarganya. Penelitian ini dapat memberikan informasi penting tentang pengelolaan interaksi sosial dalam PAUD inklusif dengan menempatkan penekanan dalam empat aspek yang dijelaskan di atas, dan juga peran orangtua dan pengajar PAUD dalam kegiatan yang bisa membantu merangsang kebutuhan spesifik dari keterampilan sosial pada anakanak dengan disabilitas intelektual.
\end{abstract}

Kata kunci: prososial; anak-anak; disabiltas intelektual

\title{
INTRODUCTION
}

A household survey conducted by UNICEF and University of Wisconsin in year 2008 (UNICEF, 2013) shows that about $52.4 \%$ children aged $6-9$ years old have some kind of disability. This data shows the high prevalence of this condition that could trouble children's development especially in young children. Children in early childhood period are those who begin from prenatal development until eight years old (WHO, 2012). Young children with disabilities are the minority group that is susceptible to all kinds of environmental risks such as violence, discrimination, negligence and bad stigma (WHO, 2012). To solve these problems, leading humanitarian organizations such as 
WHO and UNICEF begun to execute a global agenda to support the development of young children with disabilities all around the world.

Indonesia has its own trouble while dealing with the prevalence of disabilities. Disabilities in Indonesia has significantly higher prevalence when compared to other countries in the South-East Asian Region, which have a similar economic profile (see Table 1). Table 1 presents the prevalence rates and the associated year for disability levels in South-East Asian countries according to the World Health Organization (WHO). This data is assumed to be underestimated as only Indonesia and Thailand used the ICF definition (SEARO-WHO, 2013). Until now, there is no existing data in the region that compares prevalence in the same year, highlighting the dearth of studies. Nevertheless, the data shows the high prevalence of disabilities in Indonesia.

Table 1.

Prevalence of Disabilities across South-East Asia

\begin{tabular}{lll}
\hline Country & Percentage (\%) & Year \\
\hline Bangladesh & 5.6 & 2005 \\
\hline Bhutan & 3.4 & 2005 \\
\hline Democratic People's Republic of Korea & 3.4 & 2007 \\
\hline India & 2.1 & 2001 \\
\hline Indonesia & 21.3 & 2006 \\
\hline Maldives & 4.7 & 2010 \\
\hline Myanmar & 2.4 & 2009 \\
\hline Nepal & 1.6 & 2001 \\
\hline Sri Lanka & 2.0 & 2001 \\
\hline Thailand & 2.9 & 2007 \\
\hline Timor-Leste & 1.5 & 2006 \\
\hline
\end{tabular}

The table shows estimates from available data from surveys or country census of different time period (SEARO-WHO, 2013). It shows that Indonesian prevalence is relatively higher compared than other countries in South-East Asian.

The 2006's data from Center of Statistics Bureau shows that around 0.7\% or approximately 2.8 million lives are those with disabilities (Astuti, 2013). The number then increased in year 2009 to $1.38 \%$ or approximately 3 million lives. This data also shows that intellectual disability has the largest population compared to other kind of disabilities (Putra \& Adhi, 2014). According to Center of Statistics Bureau, the prevalence of mental retardation reach $1-3 \%$ from total population of Indonesia, this numbered around 6.6 million lives (Astuti, 2013). This number is predicted to increase in the future. 
Children with intellectual disabilities experience a delay in mental development (underperforming intellectual function when compared to peers) which is accompanied with the inability to learn and also to adjust with his or her environment. These children have problems with short-term memory, it will be hard for them to memorize visuo-spatial as in a short-term memory psychological test (Ardina, 2012). Furthermore, children with cognitive delays may learn at a slower pace, experience a high rate of forgetting, have difficulty in regulating their behavior, and transferring learning to new events, situations, or people. They also require more adult guidance and direct instruction, may require activities that involves concrete versus abstract, and may not readily understand a lengthy verbal instructions (Kilgo \& Gargiulo, 2005).

One of the most important challenges individuals with an intellectual disability faces while interacting with their peers and other people is their deficiency in social skills. Cognitive limitation is considered to the most important factor for the inadequate social skills of students with intellectual disabilities. Greenspan and Shoultz (in Tekinarslan, Elif, \& Bülbin, 2012) stated that cognitive limitations of individuals with an intellectual disability adversely affect their decision making about how to behave in some certain situations. Therefore, it is noted that students with an intellectual disability are unable to master social skills and have difficulty in generalizing the learnt social skills in different environments.

Although social skills differ at various ages and for various ethnic and cultural groups, some skills are universal. These universal skills that are called prosocial skills comprise being positive and agreeable, being able to use relevant contextual and social cues to guide one's own behavior, and being sensitive and responsive to the interests and behavior of playmates (Mize, in Porter, 2002). One of the important components of prosocial behavior that could easily be observed in a young child's behavior is their skill to enter a social context.

The prosocial skills comprises of (Porter, 2002): (1) Observe the group before attempting entry; (2) Initiate contact by approaching, touching, gaining eye contact, vocalizing, or using another child's name; (3) Responding positively to others' invitations is a second way to gain entry to others' play; (4) Avoid disruptive actions, such as calling attention to oneself, asking questions, criticizing the way the other children are playing, or introducing new topics of conversation or new games, being too boisterous and thus out of keeping with the group, acting aggressively or destroying others' play materials; and (5) Supportive actions. Supportive behaviors tell others that potential playmates are keen to cooperate and can be trusted. Such actions comprise: Complimenting; Smiling at; Cooperating; Imitating; Sharing; Taking turns; Assisting others; Leading diplomatically (i.e. making positive play 
suggestions) to enlist other children in their play, but without being bossy; To be supportive, children also need to pay attention to relevant social cues so that they are sensitive to the needs of their playmates. In response to feedback from their peers, they need to moderate their behavior to suit their friends and respond positively when others are trying to make friends. Finally, children need to be aware of how their behavior will influence how other people respond to them; and (6) Conflict management skills. To resolve conflict peacefully with playmates, such as when their requests to enter a group are being rebuffed, children need to be persuasive and assertive rather than bossy and negotiate play activities.

To help the development of young children with disabilities in Indonesia, specifically in East Nusa Tenggara, there is a need for data that describes the specific condition and needs of young children with a specific kind of disability such as intellectual disability. A descriptive qualitative study is needed to explain the prosocial behavior shown by young children with an intellectual disability. Past studies in Indonesia have put more focus in exploring the condition of young children without disabilities (Bunga \& Klaas, 2012; Klaas \& Bunga, 2012) or older children with disabilities, specifically in finding tools to help fulfilling basic need of development (Kawuryan \& Raharjo, 2012; Suparno, Supartini, \& Purwandari, 2010).

This study aims to describe the prosocial behavior of young children with an intellectual disability in Kupang, East Nusa Tenggara. The dissemination of this study's result hopefully will increase the awareness of community of these children's specific condition and needs and then can help the community prevent various environmental risks that could harm motor, cognitive, and socialmotional development (Durkin, 2002; Grantham-McGregor et al., 2007).

\section{METHODS}

\section{Participant}

Subject with initial "I" aged 7 years old, female, and resided in Penfui sub-district, Kupang city, East Nusa Tenggara. Subject lives together with her mother and grandparents. Her father and mother got separated. Subject spends time daily mingling with adults when not at school. 


\section{Design}

This research used descriptive qualitative approach as its research method. Even though phenomenologic, ethnography and grounded theory also has their descriptive element, descriptive qualitative approach puts more stress in it. It helps researcher to describe a behavior clearly and comprehensively (Sandelowski, 2000). By describing the behavior with multiple data collecting techniques such as interview, group discussion and observation, descriptive qualitative studies aim to address specific description objectives, usually to improve awareness of the reader (Pope, Ziebland, \& Mays, 2000).

\section{Procedure}

In this study, data was gathered using direct observation and also interview sessions with the subject's parent and teacher to explore subject's profile, habits and prosocial behavior. Observation has been conducted four times in a month period that took place in subject's school and house. Mother of subject was interviewed four times. The tools used were voice recorder on cellphone and also writing tools. Questions like "how does your child show her way of caring?" and "How is your child's way of showing good attention to her friends?" were asked to the mother. Probing questions were asked occasionally to further dig out explanation of particular behaviors. A checklist was used to observe subject's ability to join a group, supportive behaviors, self-adjustment, empathy, and also caring behaviors. Playing time in school was the main event that was carefully observed.

\section{Analysis}

The data collected with observation checklist were analyzed based on the frequency of prosocial behavior and also special notes on these behaviors, considering its context. The transcribed interview data were systematically coded manually, no data analysis software was used. The research team then performed content analysis to identify findings that emerged from informants. The identified findings were then used as a complementary to the observation data. The research team met regularly for a month to share impressions, synthesis findings and discuss alternate interpretations. 


\section{RESULTS AND DISCUSSION}

The data were encoded according to the prosocial skill components explained by Porter (2002).

\section{The Ability to Join Group}

According to the observation and interview's data, subject has a good observation skill. This is shown when she meets strangers. Subject will approach the stranger cautiously. She will spend her time approximately 5 to 10 minutes to observe the new person. Her mother said that "my daughter usually will take a short peek to a stranger, whether it is adults or children, before approaching them to be friends." Subject also showed a decent contact initiation skill. This is shown by responding a person around her that is talking, either to her or to other person, willing to play together with other person/children, accept the generosity of a new person, and also attending to guests in her house. Furthermore, subject showed the ability to give positive response to her friends. This is reflected by various emotional expressions such as smiling, laughing and hand clapping. This is similar with Maulana's (in Khotimah, 2013) explanation that children with mental disability have good social approach when the situation is familiar with them, for example the presence of their parents will help the child to be more sociable.

\section{Supportive Acts}

Supportive ability in subject showed in the form of praising others that had been successful in following a command. This is expressed by hand clapping. Supportive act was also reflected by subject's habit in smiling when seeing a close person approaching. She also showed generosity in sharing her food with her close friend. She also was not afraid to take the lead when playing together with her classmates. These supportive acts were also confirmed by her mother and teacher in school. Her mother mentioned that "when compared to other children in her class, she is more often to give gifts to her friends." This finding is somehow different when compared to Amin's (1995) statement that children with intellectual disabilities were prone to social dysfunction and problems. Other environmental factors such as parents, teachers, and siblings could possibly alter the ability of the subject in showing supportive behaviors. 


\section{Self-Adjustment}

This behavior was shown when subject appeared to be able to accept reality, accepting her limitation. When subject played with her friends in the neighborhood who were not disabled, subject chose to sit back and observe the others when the others prefer not to play together with subject. She was also willing to enter and start playing when invited. This reflected the ability to adjust in unsupportive condition without holding a grudge. All of the findings show significant difference from similar study such as Sofinar (2012) that stressed out the inability of children with intellectual disabilities in showing self-adjustment ability.

\section{Empathy and Caring}

Subject loves to learn something by imitating. This was shown by her ability to attend to guests in her house. She was quick to serve drinks and some biscuits to her guests. Her mother said that she learned this by observing her mother, when her mother attended to house guests in the past. Her mother also said that "she is a quick learner, especially in copying good and desired behaviors."

From the descriptions above, it could be seen that subject learned the way of prosocial behavior by imitating other's behavior, especially their secure attachment. The development theory by Piaget (Santrock, 2012) explained that children build their knowledge and wisdom by interacting with their environment. Children are not passive objects in receiving knowledge, but rather active in organizing their own experience into a complex mental structure. These mental structures are assimilation, accommodation and balance. Subject has a tendency to imitate, reflect her ability to assimilate, accommodate and then reproduce behaviors. This tendency also rejects the previous finding saying that children with mental retardation will experience huge difficulty during attachment forming to their parents (Gaedt, in Dosen \& Day, 2001).

It was also observed that subject's prosocial behaviors were often present when there is an object of interest that was successful in getting her attention. Subject also tended to voluntarily socialize with others when she got a gift in forward. This finding strengthens the explanation of Luby (2006) that children are egoistic humans, helping others not because wanting to make the other person happy, but to satisfy his or herself and to find their own happiness. It was also found that subject's emotional limitations showed whenever she feels angry. She tends to spit, bite, and hit others when she got mad with that person. This was addressed quickly because a child with intellectual disability has a potential to experience emotional disorder, too (Luby, 2006; Porter, 2002). A proper stimulation and 
learning environment could make children learn how to manage and control self in all sorts of emotion and condition.

To sum it up, based on this study, young children with intellectual disability have a pretty decent prosocial skills reflected by the ability to join groups, acting supportive to others, adjusting self in the objectionable social environment, and showing care to other person. Explanations concerning social ability of children with intellectual disabilities remains inconclusive because there were different results in the past studies. Parents and tutors are advised to further stimulate existing prosocial skills into a more complete state, which is acting kind and acting prosocial with selfless mentality. Positive social skills will bring great impact to the development of children, especially when entering the community as adults. Developing comprehensive programs that address specific environmental risk factors while providing appropriate levels of social protection and integrated and affordable basic services are important to reduce environmental risk factors for young children with disabilities and also support their development process (Due, Bunga, \& Kiling, 2014; Engle et al., 2007; Lansdown, 2005; McConachie et al., 2001; UNICEF, 2012).

\section{CONCLUSION AND SUGGESTIONS}

\section{Conclusion}

This study described the prosocial behavior of young children with an intellectual disability. Starting to address the needs of young children with most common disabilities in Indonesia will benefit the country in preparing the gold generation in 2045.

\section{Theoretical Suggestions}

Theoretical development in the topic of young children with intellectual disabilities is still scarce. More research is needed to develop more theories, models and frameworks in this particular area. Grounded theory and logic model approach is some approaches recommended in developing emic based theories. In the meantime, theories of young children in general or without disabilities could serve as the foundation basis in exploring the development of young children with intellectual disabilities.

To further improve similar research in the future, more subjects are needed to be included. This is somehow difficult since parents in rural province such as East Nusa Tenggara tend to hide their 
children from the community. Researcher needs to be more persistent in locating these children whereabouts. Another suggestion is to do a combination of deductive and inductive analysis. This could be done by identifying codes based on determined theories or framework (deductive), and also directly from the dataset without using any pre-determined framework (inductive). This approach could help in making sure no additional and unique findings to be missed in the analysis process.

\section{Practical Suggestions}

According to this research, parents and tutors should build an environment that could stimulate the development of selfless mentality. Existing prosocial behaviors learnt by imitating secure attachment will become more favorable when it is followed by selfless attitude. A proper preparation in development environment such as ECCD and family will give advantage to young children with an intellectual disability. By developing children with an intellectual disability hopefully will turn them into an independent adult who are ready to enter the community and contribute to the good of the nation.

\section{REFERENCES}

Amin, M. (1995). Ortopedagogik Anak Tunagrahita. Jakarta: Depdikbud.

Ardina, M. D. (2012). Implementasi pembelajaran musik untuk mengembangkan mental dan psikomotorik anak penderita down syndrom. Harmonia, 12(2), 125-131.

Astuti Y. C. (2013). Hubungan antara dukungan sosial dengan coping strategy pada ibu yang memiliki anak penyandang tunagrahita (studi korelasional pada ibu yang memiliki anak tunagrahita di SLB-C YPLB Cipaganti Kota Bandung). Ditemu kembali dari http://repository.upi.edu/3885/4/S_PSI_0800932_Chapter1.pdf.

Bunga, B. N., \& Klaas, M. A. N. (2012). The role of traditional games kayu do'i in child counseling processes. In S. Kartadinata (ed.), The 1st International Seminar on Guidance and Counseling (ISGC), 63-72.

Dosen, A., \& Day, K. (2001). Treating mental illness and behavior disorders in children and adults with mental retardation. Washington, DC: American Psychiatric Press. 
Due, R. A., Bunga, B. N., \& Kiling, I. Y. (2014). Pola bermain anak usia dini tunagrahita di Kupang. Jurnal Transformasi Edukasi, 3(2), 21-27.

Durkin, M. (2002). The epidemiology of developmental disabilities in low-income countries. Mental Retardation and Developmental Disabilities, 8, 206-211.

Engle, P. L., Black, M. M., Behrman, J. R., Mello, M. C. D., Gertler, P. J., Kapiriri, L., \& the International Child Development Steering Group. (2007). Strategies to avoid the loss of developmental potential in more than 200 million children in the developing world. Lancet, $369,141-163$.

Grantham-McGregor, S., Cheung, Y. B., Cueta, S., Richter, L., Strupp, B., \& International Child Development Steering Group (2007). Developmental potential in the first 5 years for children in developing countries. Lancet, 369, 60-70.

Kawuryan, F., \& Raharjo, T. (2012). Pengaruh stimulasi visual untuk meningkatkan kemampuan membaca pada anak disleksia. Jurnal Psikologi Pitutur, 1(1), 9-20.

Khotimah, S. N. (2013). Upaya penanganan gangguan interaksi sosial pada anak autis di yayasan austik fajar nugraha (Unpublished Bachelor's Thesis). UIN Sunan Kalijaga Yogyakarta, Indonesia.

Kilgo, J. L., \& Gargiulo, R. M. (2005). Young children with special needs: An introduction to early childhood special education. Mason: Delmar Cengage Learning.

Klaas, M. A. N., \& Bunga, B. N. (2012). The function of traditional games siki doka in guidance and counseling: A cross-cultural study. In S. Kartadinata (ed.), The 1st International Seminar on Guidance and Counseling (ISGC), 49-54.

Lansdown, G. (2005). The evolving capacities of the child. Florence, Italy: Innocenti Research Centre.

Luby, J. L. (2006). Handbook of preschool mental health: Development, disorders, and treatment. New York, NY: The Guilford Press.

McConachie, H., Huq, S., Munir, S., Kamrunnahar, Akhter, N., Ferdous, S., \& Khan, N. Z. (2001). Difficulties for mothers in using early intervention service for children with cerebral palsy in Bangladesh. Child: Care, Health and Development, 27(1), 1-12.

Pope, C., Ziebland, S., \& Mays, N. (2000). Qualitative research in health care: Analyzing qualitative data. British Medical Journal, 320, 114-116.

Porter, L. (2002). Educating young children with additional needs. Crows Nest, NSW, Australia: Allen \& Unwin. 
Putra, I. K. A. S., \& Adhi, K. T. (2014). Status gizi penyandang cacat (tunagrahita dan tunarungu) di sekolah luar biasa b negeri pembina tingkat nasional kelurahan jimbaran kabupaten badung. Community Health, 2(1), 32-41.

Sandelowski, M. (2000). Whatever happened to qualitative description? Research in Nursing \& Health, $23,334-340$.

Santrock, J. W. (2012). Life-span development. New York, NY: McGraw-Hill.

SEARO-WHO (2013). Disability in the South-East Asia Region, 2013. Ditemu kembali dari http://www.searo.who.int/entity/disabilities_injury_rehabilitation/topics/disability_factsheet. pdf

Sofinar (2012). Perilaku sosial anak tunak grahita sedang. Jurnal Ilmiah Pendidikan Khusus, 1(1), 133141.

Suparno, Supartini, E., \& Purwandari. (2010). Pengembangan model modifikasi perilaku sosial melalui media belajar berkonsep konvergensi bagi anak autis. Jurnal Kependidikan, 40(2), 201-214.

Tekinarslan, İ. Ç., Elif, S. P., \& Bülbin, S. (2012). Teachers' and mothers' assessment of social skills of students with mental retardation. Educational Sciences: Theory \& Practice, 12(4), 27832788.

UNICEF. (2012). Integrated social protection systems: Enhancing equity for children. Ditemu kembali dari http://www.unicef.org/socialprotection/framework/files/Full_Social_Protection_Strategic_Fr amework_low_res(1).pdf

UNICEF. (2013). The state of worlds's children 2013: Children with disabilities. Ditemu kembali dari http://www.unicef.org/sowc2013/

WHO. (2012). WHO and UNICEF encourage discussion and action on early childhood development and disability: A discussion paper. Ditemu kembali dari http://www.who.int/disabilities/media/news/2012/13_09/en/ 